\title{
Importance of patents and data exclusivity in fixed-dose combination medicinal products
}

\author{
Marija Mitkovska $^{1 *}$, Katerina Anchevska Netkovska ${ }^{2}$, Aleksandra Grozdanova $^{2}$, \\ Ana Poceva Panovska ${ }^{2}$, Ema Kikovska Stojanovska ${ }^{1}$ \\ ${ }^{1}$ Alkaloid AD Skopje, Blvd. Aleksandar Makedonski 12, 1000 Skopje, \\ Republic of North Macedonia \\ ${ }^{2}$ Faculty of Pharmacy, Ss. Cyril and Methodius University, Mother Theresa 47, 1000 Skopje, \\ Republic of North Macedonia
}

Received: May 2019; Accepted: June 2019

\begin{abstract}
The efficacy of an active compound can be advantageously improved when combined with other active compounds. Medicinal products for a particular indication(s) that contain combination of two or more active compounds in a fixed dose ratio is so called fixeddose combination medicinal products or FDCs. FDCs are beneficial for patients' adherence to the treatment because of the simplified drug regimen. They are used in the treatment of a wide range of medical conditions especially in the treatment of chronic illnesses including AIDS, type 2 diabetes, and many cardiovascular diseases. FDCs as other medicines are subject to variety of intellectual property rights protection (IPRs), including patents and data protection. Different jurisdictions worldwide have different standards when determining the eligibility of FDCs for patent and/or data protection. They can vary from 1) cases with lower standards for assessing the inventive step, where FDCs are given additional combination patent rights, 2) cases where FDCs is given status of new chemical entities thus allowing supplementary protection certificates and 3) cases where additional data protection for FDCs of already known active compounds is allowed. In this study, we have assessed the national standards among different jurisdictions of developing and developed countries. A comparison of their approaches in respect to their benefits and deficiencies related to the originators, patient accessibility and public health policies has been made.
\end{abstract}

Keywords: Fixed-dose combination medicinal products, patents, data exclusivity

\section{Introduction}

The development of FDCs is becoming increasingly high either to improve compliance or to benefit from the added effects of the two or more active drugs given together. Each fixed dose combination should be carefully justified and clinically relevant (CDSCO, 2010; Gupta et al., 2016). The development of FDCs are becoming increasingly important from patient and public health perspectives because of the simplified drug regimen, less costs than that of separate products given concurrently, pharmacokinetic advantage, improvement in treatment response, lower risk of developing resistance, and lower rates of adverse events (FDA Center for Drug Evaluation and Research, 2014; Gupta et al., 2016;_World Health Organization, 2005). Improved patient adherence and reduced development of resistance in the case of antimicrobials can be difficult to prove, but may be of additional benefit (World Health Organization, 2005). FDCs are used in the treatment of a wide range of chronic illnesses, including infectious diseases like AIDS, then

\footnotetext{
*mnikova@alkaloid.com.mk
} 
type 2 diabetes, and many cardiovascular diseases (CDSCO, 2010; FDA Center for Drug Evaluation and Research, 2014).

FDCs, as other medicines, are subject to variety of intellectual property right (IPR) protection. IPRs are legal rights, which allows protection of works resulting from an intellectual creation. The common IPRs include patents, copyrights, trademarks, industrial designs etc. Among others, FDCs are subject to patent protection and data exclusivity as an additional intellectual property right.

Patents are exclusive rights granted by national authority to an inventor to exclude others from commercially exploiting the invention for a limited period, in return for the disclosure of the invention, so that others may gain the benefit of the invention (World Intellectual Property Organization, 2004). The lifetime of a patent right is 20 years from the date of the patent application submission (TRIPS agreement, 1994. Article 33). In many countries, extending the lifetime of the patent up to 5 years is also applicable. This is sui generis intellectual property right and in Europe is so-called Supplementary Protection Certificate (SPC). However, this right applies only to products that undergo marketing approval for their placement on the markets, like pharmaceutical products (Official Journal of European Union, 2009).

Data exclusivity is period from the initial marketing authorization of the reference product during which generic product applicants cannot rely on the dossier of the reference product for the purposes of submitting an application, obtaining marketing authorization or placing the product on the market (European Commission, 2015). This period is different among different jurisdictions.

For example, in EU according to Article 10(1) from the Directive 2001/83/EC as amended by Directive 2004/27/EC:

"... the applicants shall not be required to provide the results of pre-clinical tests and of clinical trials if they can demonstrate that the medicinal product is a generic of a reference medicinal product which is or has been authorized for not less than eight years in a Member State or in the Community".

Market exclusivity is period when valid applications for generic products can be submitted and lead to granting of a marketing authorization, but cannot be placed on the market for additional 2 years (European Commission, 2015).

According to Article 10(2), Directive 2004/27/EC from the Directive 2001/83/EC as amended by Directive 2004/27/EC:

“... A generic medicinal product authorized pursuant Article 10.1 shall not be placed on the market until ten years have elapsed from the initial authorization of the reference product".

This is the new data exclusivity regime in Europe and does not apply to those reference medicinal products for which the initial application for authorization was submitted before $20^{\text {th }}$ of November 2005 (European Commission, 2015).

The aim of this study was to show how countries member states of WTO (World Trade Organization) signatory of TRIPS agreement (Trade-Related Aspects of Intellectual Property Rights) interpret and practices intellectual property rights on a national level and how the implementation influences the originator companies, drug patient accessibility and public health policies.

\section{Materials and methods}

For the purpose of this study, we have selected antidiabetic, cardiovascular and anti-HIV FDCs drugs. The source for selecting the FDCs was the patent database Ark Patent Intelligence. Then patent searching for the compound / combination patent and data exclusivity of the selected FDCs was made using the following patent searching databases: Ark Patent Intelligence, Espacenet, EPO and national patent searching databases. Additionally, a comparison of the patent and data exclusivity info was made in the following countries: Europe, Switzerland, Russia, Ukraine, Canada and USA. The selection of the countries was made on a basis of different interpretation and implementation of Article 39.3 (Protection of undisclosed data) of TRIPS agreement.

\section{Results and Discussion}

In this study, we have assessed different standards for determining the eligibility of FDCs for patent and/or data protection among different countries. A comparison of their approaches in respect to their benefits and deficiencies related to the originators, patient accessibility and public health policies has been made. Different jurisdictions worldwide have different standards when determining the eligibility of FDCs for patent and/or data protection.

The lifetime of a compound and combination patent according to Article 33 of TRIPS agreement is 20 years from the date of filling of a patent application and it is implemented in all countries stated above. A supplementary Protection Certificate (SPC) or a patent term extension expands the lifetime of the first compound/combination patent for a particular pharmaceutical product up to 5 years and it also applies to all countries stated above.

Even though, the selected countries are member states of WTO and are signatory of TRIPS agreement, the implementation and practices of some intellectual property rights, like protection of undisclosed data (Article 39.3 of TRIPS agreement) differ on a national level. Contrary to patents and their extensions, the protection of undisclosed data, or the so-called data exclusivity period differs from country to country: 
Table 1. Patent and data protection data for Vipidia ${ }^{\circledR}$ (antidiabetic drug)

\begin{tabular}{|c|c|c|c|c|c|c|}
\hline \multirow{2}{*}{$\begin{array}{l}\text { INN } \\
\text { Originator }\end{array}$} & \multicolumn{6}{|c|}{ ALOGLIPTIN } \\
\hline & Vipidia $^{\circledR}($ Ta & da) & & & & \\
\hline & EU & $\mathrm{CH}$ & RU & UA & CA & US \\
\hline compound patent & 21.12 .2024 & 21.12 .2024 & 15.12 .2024 & 15.12 .2024 & 21.12 .2024 & 15.03 .2025 \\
\hline $\mathrm{SPC}^{*}$ & 23.09 .2028 & 21.11 .2028 & 08.10 .2029 & I & I & 02.12 .2025 \\
\hline data exclusivity & 19.09 .2021 & 21.11 .2023 & 08.10 .2018 & 19.12.2019 & 27.11 .2019 & 25.01 .2018 \\
\hline market exclusivity & 19.09 .2023 & $\mathrm{n} / \mathrm{a}$ & 08.10 .2020 & $\mathrm{n} / \mathrm{a}$ & 27.11 .2021 & $\mathrm{n} / \mathrm{a}$ \\
\hline
\end{tabular}

*Supplementary Protection Certificate (SPC)

Table 2. Patent and data protection data for Vipdomet ${ }^{\circledR}$ (antidiabetic combination)

\begin{tabular}{|c|c|c|c|c|c|c|}
\hline \multirow{3}{*}{$\begin{array}{l}\text { INN } \\
\text { Originator } \\
\end{array}$} & \multicolumn{6}{|c|}{ ALOGLIPTIN + METFORMIN } \\
\hline & Vipdomet $^{\mathbb{B}}($ & keda) & & & & \\
\hline & EU & $\mathrm{CH}$ & $\mathrm{RU}$ & UA & CA & US \\
\hline combination patent & 13.09 .2026 & 13.09 .2026 & 13.09 .2026 & 13.09 .2026 & 13.09 .2026 & 15.03 .2025 \\
\hline $\mathrm{SPC}^{*}$ & 23.09 .2028 & 19.01.2029 & 13.09.2031 & I & l & 24.06 .2025 \\
\hline data exclusivity & 19.09.2021 & $\mathrm{n} / \mathrm{a}$ & 11.12 .2021 & 03.03 .2020 & 27.11.2019 & 25.01 .2016 \\
\hline market exclusivity & 19.09.2023 & $\mathrm{n} / \mathrm{a}$ & 11.12 .2023 & $\mathrm{n} / \mathrm{a}$ & 27.11.2021 & $\mathrm{n} / \mathrm{a}$ \\
\hline
\end{tabular}

*Supplementary Protection Certificate (SPC)

Table 3. Patent and data protection data for Incresync ${ }^{\circledR}$ (antidiabetic combination)

\begin{tabular}{|c|c|c|c|c|c|c|}
\hline \multirow{3}{*}{$\begin{array}{l}\text { INN } \\
\text { Originator }\end{array}$} & \multicolumn{6}{|c|}{ " ALOGLIPTIN + PIOGLITAZONE } \\
\hline & Incresync $^{(R)}$ & keda) & & & & \\
\hline & EU & $\mathrm{CH}$ & RU & UA & CA & US \\
\hline combination patent & 13.09.2026 & 13.09.2026 & 13.09.2026 & 30.01 .2028 & 13.09.2026 & 19.06.2016 \\
\hline SPC ${ }^{*}$ & 23.09.2028 & 19.01.2029 & 08.10 .2029 & 30.01 .2033 & I & 19.06.2021 \\
\hline data exclusivity & 19.09.2021 & $\mathrm{n} / \mathrm{a}$ & not registered & 19.07.2021 & 27.11.2019 & 25.01.2016 \\
\hline market exclusivity & 19.09.2023 & $\mathrm{n} / \mathrm{a}$ & not registered & $\mathrm{n} / \mathrm{a}$ & 27.11 .2021 & $\mathrm{n} / \mathrm{a}$ \\
\hline
\end{tabular}

*Supplementary Protection Certificate (SPC)

Table 4. Patent and data protection data for Ziagen ${ }^{\circledR}$ (anti-HIV drug)

\begin{tabular}{|c|c|c|c|c|c|c|}
\hline \multirow{3}{*}{$\begin{array}{l}\text { INN } \\
\text { Originator }\end{array}$} & $\overline{\text { ABACAVIR }}$ & & & & & \\
\hline & \multicolumn{6}{|c|}{ Ziagen $^{B}$ (ViiV Healthcare) } \\
\hline & EU & $\mathrm{CH}$ & RU & UA & CA & US \\
\hline compound patent & 21.12 .2010 & 21.12 .2010 & 21.12 .2010 & 21.12 .2010 & 08.06 .2016 & 21.12 .2010 \\
\hline SPC & 28.06 .2014 & 28.06 .2014 & I & I & I & 18.12 .2011 \\
\hline data exclusivity & 28.06.2009 & 28.06 .2009 & $\mathrm{n} / \mathrm{a}$ & 14.10 .2010 & $\mathrm{n} / \mathrm{a}$ & 02.08 .2007 \\
\hline market exclusivity & $\mathrm{n} / \mathrm{a}^{*}$ & $\mathrm{n} / \mathrm{a}$ & $\mathrm{n} / \mathrm{a}$ & $\mathrm{n} / \mathrm{a}$ & $\mathrm{n} / \mathrm{a}$ & $\mathrm{n} / \mathrm{a}$ \\
\hline
\end{tabular}

*Supplementary Protection Certificate (SPC) 
Table 5. Patent and data protection data for Kivexa ${ }^{\circledR}$ (anti-HIV combination)

\begin{tabular}{|c|c|c|c|c|c|c|}
\hline \multirow{3}{*}{$\begin{array}{l}\text { INN } \\
\text { Originator } \\
\end{array}$} & \multicolumn{6}{|c|}{ "ABACAVIR + LAMIVUDINE } \\
\hline & \multicolumn{6}{|c|}{ Kivexa $^{(B)}$ (ViiV Healthcare) } \\
\hline & EU & $\mathrm{CH}$ & RU & UA & $\mathrm{CA}$ & US \\
\hline combination patent & 28.03 .2016 & 28.03 .2016 & 28.03 .2016 & 28.03 .2016 & 28.03 .2016 & 28.03 .2016 \\
\hline $\mathrm{SPC}^{*}$ & 17.12 .2019 & 30.10 .2020 & 28.03 .2021 & / & / & l \\
\hline data exclusivity & 22.12 .2014 & 22.12 .2016 & $\mathrm{n} / \mathrm{a}$ & 21.10 .2015 & $\mathrm{n} / \mathrm{a}$ & 29.03.2017 \\
\hline market exclusivity & 22.12 .2016 & $\mathrm{n} / \mathrm{a}$ & $\mathrm{n} / \mathrm{a}$ & $\mathrm{n} / \mathrm{a}$ & $\mathrm{n} / \mathrm{a}$ & $\mathrm{n} / \mathrm{a}$ \\
\hline
\end{tabular}

*Supplementary Protection Certificate (SPC)

Table 6. Patent and data protection data for Triumeq ${ }^{\circledR}$ (anti-HIV combination)

\begin{tabular}{|c|c|c|c|c|c|c|}
\hline \multirow{3}{*}{$\begin{array}{l}\text { INN } \\
\text { Originator }\end{array}$} & \multicolumn{6}{|c|}{ ABACAVIR + LAMIVUDINE + DOLUTEGRAVIR } \\
\hline & \multicolumn{6}{|c|}{ Triumeq $^{(\mathbb{R}}$ (ViiV Healthcare) } \\
\hline & EU & $\mathrm{CH}$ & RU & UA & $\mathrm{CA}$ & US \\
\hline combination patent & 24.01 .2031 & 24.01 .2031 & 24.01 .2031 & 24.01 .2031 & 24.01 .2031 & 24.01 .2031 \\
\hline $\mathrm{SPC}^{*}$ & / & / & / & / & l & I \\
\hline data exclusivity & 16.01.2022 & $\mathrm{n} / \mathrm{a}$ & not registered & 29.12 .2020 & 31.10 .2019 & 12.08.2018 \\
\hline market exclusivity & 16.01.2024 & $\mathrm{n} / \mathrm{a}$ & not registered & $\mathrm{n} / \mathrm{a}$ & 31.10 .2021 & $\mathrm{n} / \mathrm{a}$ \\
\hline
\end{tabular}

*Supplementary Protection Certificate (SPC)

Table 7. Patent and data protection data for Rasilez ${ }^{\circledR}$ (cardiovascular drug)

\begin{tabular}{|c|c|c|c|c|c|c|}
\hline \multirow{3}{*}{$\begin{array}{l}\text { INN } \\
\text { Originator } \\
\end{array}$} & \multicolumn{6}{|c|}{ "ALISKIREN } \\
\hline & \multicolumn{6}{|c|}{ Rasilez $^{(R)}$ (Novartis) } \\
\hline & EU & $\mathrm{CH}$ & $\mathrm{RU}$ & $\mathrm{UA}$ & $\overline{\mathrm{CA}}$ & US \\
\hline compound patent & 07.04 .2015 & 07.04 .2015 & 13.04 .2015 & / & 13.04 .2015 & 04.04 .2015 \\
\hline $\mathrm{SPC}^{*}$ & 07.04 .2020 & 07.04 .2020 & / & / & / & 21.07.2018 \\
\hline data exclusivity & 24.08 .2015 & 29.06 .2017 & not registered & not registered & 14.11 .2013 & 05.03 .2012 \\
\hline market exclusivity & 24.08 .2017 & $\mathrm{n} / \mathrm{a}$ & not registered & $\mathrm{n} / \mathrm{a}$ & 14.11.2015 & $\mathrm{n} / \mathrm{a}$ \\
\hline
\end{tabular}

*Supplementary Protection Certificate (SPC)

Table 8. Patent and data protection data for Rasilez ${ }^{\circledR}$ HCT (cardiovascular combination)

\begin{tabular}{lcccccr}
\hline \hline INN & \multicolumn{2}{l}{ ALISKIREN + HCTZ } & & & \\
\hline Originator & \multicolumn{2}{l}{ Rasilez $^{(B}$ HCT (Novartis) } & & & UA & CA \\
\hline combination patent & 07.04 .2015 & 07.04 .2015 & 15.11 .2021 & $/$ & 13.04 .2015 & 04.04 .2015 \\
SPC & 07.04 .2020 & 07.04 .2020 & 30.07 .2025 & $/$ & $/$ & 21.07 .2018 \\
data exclusivity & 16.01 .2017 & n/a & not registered & not registered & 14.11 .2013 & 05.03 .2012 \\
market exclusivity & 16.01 .2019 & n/a & not registered & n/a & 14.11 .2015 & n/a \\
\hline
\end{tabular}

*Supplementary Protection Certificate (SPC) 
Table 9. Data exclusivity periods in different jurisdictions

\begin{tabular}{cc}
\hline \hline jurisdiction & data exclusivity period \\
\hline European Union & 8 years \\
Switzerland & 10 years \\
Russia & 4 years \\
Canada & 6 years \\
Ukraine & 5 years \\
USA & 5 years \\
\hline
\end{tabular}

Market exclusivity period is 2 years and is applicable in Europe, Russia and Canada. In comparison with the old data exclusivity regime in Europe, market exclusivity allows generic companies to submit their applications for marketing authorization 2 years earlier than before, thus allowing entering the European market immediately after the expiry of the market exclusivity. Contrary to Europe, Russia and Canada, market exclusivity in Switzerland, Ukraine and USA has not been implemented. In Ukraine and USA, there is so-called "patent linkage" where submission for marketing authorization is additionally blocked with existing patent in force. If patent expires after the data exclusivity period, which is usually the case, the submission for marketing authorization in Ukraine and USA will be defined with the expiry date of the relevant patent. The drugs registered in Europe before November 2005, like Ziagen ${ }^{\mathbb{R}}$ are not subject to market exclusivity, since they are subject to the old data exclusivity regime. The drugs registered in Russia before August 2012, like Ziagen ${ }^{\circledR}$ and Kivexa ${ }^{\circledR}$ are not subject to data and market exclusivity. In August 2012, Russia has become a WTO (World Trade Organization) member, when data exclusivity regime was implemented. In Canada, data and market exclusivity were introduced on $17^{\text {th }}$ of June 2006. Therefore, drugs registered before $17^{\text {th }}$ of June 2006, like Ziagen ${ }^{\circledR}$ and Kivexa ${ }^{\circledR}$, as well are not subject to data and market exclusivity.

\section{Conclusion}

FDCs are subject to patent and SPC protection / patent term extension in all countries stated above. FDCs are not eligible for data exclusivity in Switzerland, if all active compounds are already known. For example, Vipdomet $^{\circledR}$, Incresync $^{\circledR}$, Triumeq ${ }^{\circledR}$ and Rasilez ${ }^{\circledR}$ HCT are not subject to data exclusivity in Switzerland. Nevertheless, if new indications, new modes of administration, new dosages and new forms are found, they will be eligible for 3 years period of data exclusivity. In general, market exclusivity for FDCs is defined with the SPC or patent term extension, especially in countries like Ukraine and USA where submissions for marketing authorizations are dictated with a relevant patent in force.

\section{References}

CDSCO, 2010. Guidance for Industry on Fixed-dose Combinations (FDCs), 4.

European Commission, 2015. The Rules governing Medicinal Products in the European Union,

The Notice to Applicants, Volume 2A Procedures for marketing authorization, Chapter 1 Marketing Authorization, 39-40. Available at:

https://ec.europa.eu/health/sites/health/files/files/eudralex/v ol-2/vol2a_chap1_en.pdf.

FDA Center for Drug Evaluation and Research, 2014. New Chemical Entity Exclusivity Determinations for Certain Fixed Combination Drug Products Guidance for Industry guideline, 2. Available at: https://www.fda.gov/media/87932/download.

Gupta, Y.K., Ramachandran, S.S., 2016. Fixed-dose drug combinations: Issues and challenges in India. Available at: https://doi.org/ 10.4103/0253-7613.186200.

Official Journal of European Union, 2009. Regulation (EC) No 469/2009, 2. Available at: https://eurlex.europa.eu/LexUriServ/LexUriServ.do?uri=OJ:L:2009:1 52:0001:0010:en:PDF.

TRIPS agreement, 1994. Article 33. Available at: https://www.wto.org/english/docs_e/legal_e/27trips_04c_e.htm\#fnt-8.

World Health Organization, 2005. WHO Technical Report Series, No. 929, 95-96. Available at: https://apps.who.int/iris/bitstream/handle/10665/43157/WH O_TRS_929_eng.pdf?sequence=1.

World Intellectual Property Organization, 2004. WIPO Intellectual Property Handbook, 17. Available at: https://www.wipo.int/edocs/pubdocs/en/intproperty/489/wi po_pub_489.pdf. 


\title{
Резиме
}

\section{Важноста на патентите и ексклузивноста на податоци за фиксно-дозните комбинирани медицински производи}

\author{
Марија Митковска ${ }^{1 *}$, Катерина Анчевска-Нетковска ${ }^{2}$, Александра Грозданова ${ }^{2}$, \\ Ана Поцева-Пановска ${ }^{2}$, Ема Киковска-Стојановска ${ }^{2}$ \\ ${ }^{1}$ Алкалоид АД Скопје, бул. Александар Македонски 12, 1000 Скопје, \\ Република Северна Македонија \\ ${ }^{2}$ Фармацевтски факултет, Универзитет „Св.Кирил и Методиј”, Мајка Тереза 47, \\ 1000 Скопје, Република Северна Македонија
}

Клучни зборови: Фиксно-дозни комбинирани медицински производи, патенти, ексклузивност на податоци

Ефикасноста на една активна компонента може да биде значително подобрена во комбинација со други активни компоненти. Медицински производи за одредена индикација кои содржат две или повеќе активни компоненти во фиксно-дозен однос се т.н. фиксно-дозни комбинирани медицински производи (ФДК). ФДК се корисни за придржувањето на пациентите кон третман поради поедноставување на дозниот режим. Се користат во третман на широк опсег на медицински состојби, особено во третман на хронични заболувања вклучувајќи СИДА, тип-2 дијабетес, и многу кардиоваскуларни заболувања. ФДК како и други лекови се предмет на заштита на различни права од интелектуална сопственост (ПИС), вклучувајќки патенти и заштита на податоци. Различни национални органи имаат различни стандарди при утврдување на подобноста на ФДК за патентна заштита и/или заштита на податоци. Тие може да варираат од 1) случаи со пониски стандарди за оценување на инвентивен придонес, каде на ФДК се доделуваат дополнителни патентни права на комбинацијата, 2) случаи каде на ФДК е доделен статус на нов хемиски ентитет, а со тоа им се овозможува и дополнителна заштита на патент и 3) случаи каде е овозможена дополнителна заштита на податоци на ФДК на веќе познати активни соединениеја. Во овој труд се проценети националните стандарди помеѓу различни правни органи на развиените земји и земјите во развој. Направена е споредба на нивниот пристап во однос на нивните бенефиции и недостатоци поврзани со оригинаторите, достапноста на пациентите и политиките за јавно здравје. 